\title{
NONPARASITIC WARLORDS AND GEOGRAPHIC DISTANCE
}

\section{JERRY HIONIS}

Jerry Hionis is Visiting Assistant Professor of Economics at Widener University in Chester, PA. He can be reached at jhionis@gmail.com.

\section{Abstract}

The explicit consideration of geography in the conflict theory literature is still relatively rare. In this article, two warlords are modeled as being located at opposing ends of a hypothetical line. The model includes variables denoting distance and difficulty of terrain. Each warlord allocates resources to the extraction of natural resources, to the production of goods and services (hence, nonparasitic), and to conflict with the opposing warlord. Two forms of a contest success function, a primary tool in the literature, are used to show that the warlord closer to the point of conflict will invest less into the hiring of warriors and more into the production of goods and services, yet will win a larger proportion of total goods and services produced within the economy.

$\mathrm{S}$ ince the second world war, at least 158 distinct armed conflicts have been recorded, with close to 41 million civilian and military deaths, a toll that exceeds the entire current population of Argentina. Conflicts differ in terms of scope, structure, and method and the conflict theory literature thus distinguishes among conflict types: intrastate, interstate, extrastate, nonstate, insurgency, civil war and so on. State-to-state style conflicts were more prevalent before the 1960s; since then we observe an increasing number of civil and nonstate armed engagements. Typically characterized by two or more contesting groups within a single state, one of the contestants is either an established ruling group, or no established ruler exists, or nonstate groups are fighting among each within the theater of a much larger civil war against an established ruler. Ninety-five such nonstate conflicts have been identified between 1816 and 2007, and one can expect this number to rise given the current destabilizing conflicts in Syria, Iraq, Pakistan, South Sudan, and elsewhere. Due to certain ambiguities in many of these nonstate conflicts, other conflict scenarios that do not involve well-defined armies, such as organized crime and gang warfare, hold many of the same microeconomic foundations. ${ }^{1}$

Close to 1.5 billion people (roughly 21 percent of the global population) live in countries that suffer from varying levels of violent conflict due to organized crime, political struggle or, in general, high crime and murder rates due to political instability. While some nonstate conflicts erupt between warlords who use an economy's resources strictly for their own gain, there are others where warlords use these resources for conflict and investment in the future of the economy as a whole. Such cases can be found, in varying degrees, in the conflicts taking place in developing economies, as well as in the history of organized crime syndicates such as the yakuza and the mafia. ${ }^{2}$

A warlord economy is an economy or state where individuals, known as warlords, compete against each other by offering protection and battling over rents, such as from oil, diamonds, and other natural resources, instead of engaging in the production of marketable goods and services. There has recently been an interest in studying the relationship between nonstate and civil war-like conflicts and geographical factors. These studies are less inclined to forecast how conflicts will arise and instead focus on where and how these conflicts are fought. The intensity and duration of such conflicts are shown to be dependent not only on the total geographical area but also on the conflict's proximity from the capital city (or the area with the highest population density) and the border. Two sets of results are found. First, conflict is more likely to erupt in rural areas and along national borders. Second, along the lines of Kilcullen's hypothesis regarding an increasing trend of urban guerrilla warfare, there exists a correlation between a warlord's proximity to the capital and the likelihood of conflict. These two opposing results emphasize the difference between two variations of civil conflict: wars waged as an insurgency of a group against an established government presence, and a territorial conflict among warlords where no established government holds control. In addition, stronger and more skilled insurgency groups are prone to be closer to the capital while weaker groups are based further away. ${ }^{3}$

While the importance of geographic distance on conflict has been shown empirically, current theoretical models do not often consider such effects. Early models of insurgency have focused on both territorial expansion and the effect that conflict has on geographic location of insurgence. The effect that the geographic location of conflict may have on wartime 
decisionmaking has been given much less attention. In an early study, Kenneth Boulding put special emphasis on the role that distance and geography have on firm competition, international relations, the definition of "boundaries," and the role of long-range artillery. Merging sociological concepts of conflict with theoretical models by Hotelling and Richardson, Boulding proposes a loss-of-strength gradient, a measure of an agent's force or potency over distance, and argues that this gradient decreases as distance to one's home location increases. Of the few recent formal studies on the effect of geography on decisionmaking within a conflict, the work by Scott Gates is of special importance. Gates constructs a principal-agent model to study how an insurgent leader and an established ruler each construct a system of rewards and punishments to retain support. The model is built upon a geographical framework in that both the insurgent leader and the established ruler are located at distinct areas with varying distances from possible supporters. Under general conditions, Gates shows that more distant supporters are rewarded more than those closer to the associated leader. ${ }^{4}$

The model presented in the present article adds to the literature by narrowing in on how conflict location affects expenditures on war efforts and the production of goods and services.

\section{A model of warlord conflict}

\section{Type of conflict}

Models of civil and nonstate conflicts usually assume that at least the usurper, if not the incumbent as well, acts in a purely parasitic manner, that is, using an economy's resources to win political and/or economic control and never investing within the economy itself. A rich set of "guns-and-butter" models exists where leaders' decisions involve both the expenditure of resources toward production of goods and services and/or the appropriation of goods and services. One key distinction between contests within a guns-and-butter economy and other possible contests is the notion of how the value of the "prize"- the political and/or economic goal over which players are fighting - is developed. One class of models involves exogenous prize contests in which the players' actions do not affect the value of the prize. The other class involves endogenous prize contests where players' actions directly or indirectly affect the value of the contest's prize. ${ }^{5}$

The theoretical literature pertaining to guns-and-butter economies primarily focuses on battlefield conflicts. Players are imagined as standing at different ends of a line. A key facet is that state government is either too weak to enforce law or has effectively ceased to exist. Individuals then need protection from the predator-prey system that arises and this gives rise to
This article considers the role of geography in the interplay between competing warlords. Two forms of a contest success function-a primary tool in the conflict theory literature-are used to show, inter alia, that of two warlords, the one whose base is located closer to their point of conflict will invest less into the hiring of warriors and more into the production of goods and services and correspondingly wins a larger proportion of the total amount of goods and services produced within the economy.

warlords who offer protection from competing warlords. The work presented here is an endogenous guns-and-butter model and depicts warlords as nonparasitic, i.e., showing concern for the value of the production of goods and services in the economy. ${ }^{6}$

\section{Structure of the economy and conflict}

Conflict models define each warlord as having control over a territory, endowed with natural resources, and commanding a group of loyal subjects. The models rarely, if ever, consider geographic distance between warlords as affecting their decisionmaking. Likewise, the budget constraints found in many models do not reflect warlords' true costs. For example, natural resources, such as diamonds, oil, and timber, need to be extracted in order to be sold. The cost of extraction should be taken into consideration explicitly, through wages, and implicitly, through the use of labor. Both then affect a warlord's resource balance. Loyal subjects within a warlord's populace may also seek immediate monetary compensation as opposed to a fraction of the warlord's spoils after conflict has ceased. $^{7}$

The model presented here considers an economy where two warlords, $A$ and $B$, each are in control of distinct and separate territories, $l_{A}$ and $l_{B}$, respectively, connected by a straight line of fixed length on an interval $[0,1]$, where $l_{A}=0$ and $l_{B}=1$. Each warlord's strategy set includes three economic activities: (1) producing goods and services, (2) extracting and selling natural resources, and (3) appropriating goods and services produced by the opposing warlord through force. Within each territory, the ruling warlord is endowed with three important resources used to perform the mentioned economic activities: (1) a population of loyal subjects, $N_{A}$ and $N_{B}$, (2) a preexisting budget, $Y_{A}$ and $Y_{B}$, and (3) a cache of unextracted natural resources, $R_{A}$ and $R_{B}{ }^{8}$

It is assumed that each member of a warlord's population performs one, and only one, of two activities: fight as a warrior, $W_{A}$ and $W_{B}$, or work as a natural resource extractor, $E_{A}$ and $E_{B}$. This results in a population constraint for each warlord, $N_{A}=W_{A}+E_{A}$ and $N_{B}=W_{B}+E_{B}$. Each warlord pays every 
warrior a wage, $c_{w}$, and every extractor a wage, $c_{E}$, using his preexisting budget and the proceeds from sales of extracted natural resources. That is, warlords' subjects expect immediate compensation in lieu of a proportion of the conflict's spoils. After extraction, natural resources are sold to external buyers who pay a fixed exogenous price per unit of $m_{R}{ }^{9}$

Let $\hat{R}_{A}$ and $\hat{R}_{B}$ be the amount of natural resources that warlords $A$ and $B$, respectively, choose to extract. Three explicit assumptions are imposed on the model.

Assumption 1: Warlords are incapable of extracting all of the natural resources, $\hat{R}_{A}<R_{A}$ and $\hat{R}_{B}<R_{B}$.

Assumption 2: Each unit of natural resources is extracted by a single unit of extractors, $\hat{R}_{A}=E_{A}$ and $\hat{R}_{B}=E_{B}$.

Assumption 3: The price received for a natural resource unit is greater than the cost to extract it; that is, $m_{R}>c_{E}$.

Assumptions 1 and 3 are necessary to ensure an interior solution and to avoid negative prices. Assumption 2, apart from making the model less complex, speaks to the technology of natural resource extraction: It is completely labor-intensive without the use of capital.

In contrast to Assumption 3, the production of goods and services by each warlord is a function of the capital, $K_{A}$ and $K_{B}$. To facilitate production within his territory, each warlord can invest by purchasing capital from an external seller at a constant cost, $\mathrm{c}_{k}$. Further, goods and services produced by either or both warlords are sold to external buyers who pay a fixed, exogenous price per unit, $m$. Therefore, the total value of the economy is based upon the market value of both warlords' production combined, that is, $(m) \cdot\left(K_{A}+K_{B}\right){ }^{10}$

A revenue constraint for each warlord can now be constructed. It consists of two revenue streams-the preexisting budget and sales of extracted natural resources - as well as of the three explicit expenses of warrior wages, extractor wages, and payments on capital investment:

(1) $Y_{A}+\left(m_{R} \cdot \hat{R}_{A}\right)=\left(c_{w} \cdot W_{A}\right)+\left(c_{E} \cdot E_{A}\right)+\left(c_{k} \cdot K_{A}\right)$,

and, symmetrically, for warlord $B$. For aesthetic purposes, let $\sigma=m_{R}-c_{E}$. By applying Assumption 2, one can combine the population and revenue constraints such that warlord $A$ 's income maximization decision is constrained by
(2) $N_{A}+\frac{Y_{A}}{\sigma}=\left(\frac{c_{w}}{\sigma}+1\right) \cdot w_{A}+\left(\frac{c_{k}}{\sigma}\right) \cdot K_{A}$

and, symmetrically, for warlord $B$.

As opposed to extracting natural resources and financing production, each warlord also has the ability to take revenues earned by the opposing warlord through force. The area where conflict is to take place - the conflict point, denoted by $l_{c}$ - is exogenously set. The conflict point may be interpreted as the location of the highest economic and/or political importance, for instance, a capital city, a center of production, or a major port. Recalling that the geography of the economy is defined as $l_{A}=0$ and $l_{B}=1$, warlord $A$ is then located at a distance from the point of conflict of $\left(l_{c}-l_{A}\right)=l_{c}$, whereas warlord $B$ is located at a distance of $\left(l_{B}-l_{c}\right)=\left(1-l_{c}\right)$.

Given his distance from the conflict point, each warlord sets out to appropriate a portion of the economy's total production of goods and services by dedicating resources toward the so-called impact function, $I_{A}$ and $I_{B}$. Each warlord's impact on the conflict is based on three factors: (1) the number of warriors hired by each warlord, (2) the distance between each warlord's territory and the conflict point, and, (3) an exogenous scalar, $\phi>0$, that represents the cost of geographic distance (a higher value indicates an increased cost of travel and troop mobility).

Three essential properties of the impact function are held to be true. First, any increase in the number of warriors hired to fight will increase the warlord's impact on the conflict. Second, following Boulding's concept of the law of diminishing strength (the loss-of-strength gradient), an increase in the distance between the conflict point and a warlord's territory will result in a negative effect on the warlord's impact, that is, to move troops is costly. Finally, an increase in the cost of travel per se also has a negative effect on each warlord's impact. To clarify: moving troops is one thing; moving troops over mountainous terrain is another. To add robustness to the model, two explicit impact functions are used: the Gates-logit model and the subtractive model. The former is based on Gates (2002) where a warlord's impact function takes the difference between the natural logarithm of warriors hired and his distance from the conflict point: ${ }^{11}$

(3) $l_{A}=\ln \left(W_{A}\right)-\phi \cdot\left(l_{c}-l_{A}\right)^{2}$

and, symmetrically, for warlord $B$.

The subtractive model is similar to the Gates-logit except that the impact function takes the difference between the number of warriors hired (without the logarithm) and the distance from the point of conflict: 


$$
\text { (4) } l_{A}=W_{A}-\phi \cdot\left(l_{c}-l_{A}\right)^{2}
$$

and, again, symmetrically for $B$.

Using these two formulations, the contest between the two warlords is determined by a contest success function (CSF). The literature focuses on two general types of CSFs: ratio and difference. A detailed treatment of the two CSF forms is available as an online supplement to this article (Hionis, 2015). In brief, the ratio form CSF is primarily used to model contests with an "all or nothing" premise: If a contestant were to supply no resistance or effort toward a conflict, he would effectively lose everything. Conversely, the difference form CSF is used to model situations where both contestants can survive but with different portions of the prize. In addition, the exponential function in the difference form below allows for diminishing returns to conflict inputs due to factors such as geography and terrain. Given the model's focus on the effect of geographic distance on decisionmaking, the CSF to use here is the difference form because it reflects the imperfections that distance and terrain can contribute to conflict. ${ }^{12}$

Let $\pi_{A}$ and $\pi_{B}$ be the CSFs for conflict between warlords $A$ and $B$, respectively. The explicit form of the CSF for warlord $A$ is defined as $\pi_{A}=1 /\left(1+e^{\alpha \cdot\left(I_{B}-I_{B}\right.}\right)$, where $e$ is the exponential function, $\alpha$ is an exogenous mass effect variable, and $\pi_{A}=1-\pi_{B}$. Importantly, the CSF is not interpreted as the probability that warlord $A$ will defeat warlord $B$; instead, $\pi_{A}$ reflects the share of the total production of goods and services within the economy that warlord $A$ is able to acquire and retain. (Warlord $B$ acquires the remaining $1-\pi_{B}$.)

Income gained by each warlord is the total amount of production profits he is able to defend plus the amount he is able to take from the opposing warlord. Let $V_{A}$ and $V_{B}$ be the income gained by each warlord, respectively, from production and from warfare. Using the difference CSF form, warlord $A$ 's income equation is $V_{A}=\pi_{A} \cdot m \cdot\left(K_{A}+K_{B}\right)$ and similarly for $B$. Given warriors hired and capital invested by warlord $B$ (i.e., $W_{B}$ and $K_{B}$ ), warlord $A$ then seeks to maximize his share of income made on the total production within the economy subject to his population size such that

(5) $\max _{W_{A}, K_{A}} V_{A}$ s.t. $N_{A}+\frac{Y_{A}}{\sigma}=\left(\frac{c_{w}}{\sigma}+1\right) \cdot w_{A}+\left(\frac{c_{k}}{\sigma}\right) \cdot K_{A}$.

Symmetrically, given $W_{A}$ and $K_{A}$, warlord $B$ seeks to maximize his share of income made on the total production within the economy subject to his population size. (The online supplement lists and explains all the model's variables.)

\section{Solutions ${ }^{13}$}

\section{Symmetric exogenous resources}

Begin by examining the symmetric case where warlord $A$ and $B$ each are endowed with the same population and equal preexisting budgets, that is, $N_{A}=N_{B}=N$ and $Y_{A}=Y_{B}=Y$. In addition, let $W_{A}{ }^{*}, W_{B}{ }^{*}, K_{A}{ }^{*}$, and $K_{B}{ }^{*}$ signify the number of warriors hired and capital invested, respectively, by warlords $A$ and $B$ under equilibrium.

Proposition 1: Let $N_{A}=N_{B}=N$ and $Y_{A}=Y_{B}=Y$. If Assumptions 1 to 3 hold, then both the Gates-logit and the subtractive models show that $W_{A} *=W_{B} *, K_{A} *=K_{B}{ }^{*}$, and $\pi_{A}^{*}=\pi_{B}^{*}=1 / 2$ when $l_{c}=1 / 2$.

In words, the proposition states that when the conflict point is located equidistant from either warlord's territory, both warriors hire the same number of warriors and invest in the same level of capital. Given this symmetry, it is not surprising to find that each warlord will obtain the same amount of the total production of goods and services within the economy.

The second proposition illustrates the effect of moving the conflict point away from the midpoint, i.e., closer to either warlord's territory.

Proposition 2: Let $N_{A}=N_{B}=N$ and $Y_{A}=Y_{B}=Y$. If Assumptions 1 to 3 hold, and if $l_{c}$ moves away from $l_{A}=0$ toward $l_{B}=1$, then both the Gates-logit and the subtractive models show that $\mathrm{W}_{\mathrm{A}} *>\mathrm{W}_{\mathrm{B}} *$ and $\mathrm{K}_{\mathrm{A}} *<\mathrm{K}_{\mathrm{B}}$, yet the total number of warriors hired and the total amount of capital invested remains constant.

Proposition 2 asserts that the increased distance between a warlord's territory and the conflict point has an increasing effect on the warlord's hiring of warriors and a decreasing effect on his capital investment. Conversely, the warlord who is closer to the point of conflict does not need to hire as large an army of warriors - because of the shorter distance each warrior needs to travel - and thus can spend more of his resources on the production of goods and services. In contrast, the warlord who is further from the conflict point must amass a larger army and has less to spend on the production of goods and services. The proposition further states that while each warlord's individual decisions regarding production and conflict are influenced by geography, the total number of warriors hired and the total amount of production of goods and services are not. This results directly from the symmetric increase and decrease of these variables as the conflict point moves.

Whereas the second proposition focuses on distance, the 
next proposition summarizes the effect of terrain on each warlord's decisionmaking.

Proposition 3: Let $N_{A}=N_{B}=N$ and $Y_{A}=Y_{B}=Y$. If Assumptions 1 to 3 hold, then both the Gates-logit and the subtractive models show that for warlord $A$, an increase in $\phi$ will have an increasing effect on the number of warriors hired when the conflict point crosses the midpoint toward warlord $B$ 's stronghold, and a decreasing effect when the conflict point is moved closer to warlord $A$ 's territory. (And, vice versa, for for warlord $B$.)

Put differently, when the conflict point is located closer to warlord $A$ 's stronghold, an increase in the harshness or difficulty of the terrain will cause warlord $B$ to increase the number of warriors hired due to the increasingly adverse effect that distance has on warlord $B$ 's warriors. Since, from Proposition 2, warlord $A$ will hire fewer warriors when the conflict point is closer to his territory, an increase in $\phi$ will cause warlord $A$ to decrease the number of warriors hired because he is aware that warlord $B$ will have a harder time in the conflict. Conversely, when the conflict point is located closer to warlord $B$ 's stronghold, an increase in $\phi$ will cause warlord $B$ to decrease the number of warriors hired while warlord $A$ increases their number.

Even though the warlord further away from the point of conflict hires more warriors than the opposing warlord, both models conclude that this warlord does not necessarily win a larger proportion of the total production of goods and services within the economy. This is stated in the next proposition.

Proposition 4: If Assumptions 1 to 3 hold, the CSF under the subtractive model is unaffected by changes in the conflict point and, hence, is constant at $\pi_{A}^{*}=\pi_{B}^{*}=1 / 2$. But under the Gates-logit model, the CSF is affected by changes in the conflict point such that the warlord closer to the conflict point wins a larger proportion of the total production of goods and services within the economy.

According to Proposition 4, the two models differ on how geographic distance affects each warlord's CSF. Specifically, the subtractive model holds that geography has no effect, and the total production of goods and services within the economy is split equally between the two warlords. The Gates-logit model, in contrast, results in an adverse geographic effect: As the conflict point moves closer to a warlord's territory, that warlord will experience an increase in his CSF such that his winning proportion of the economy's production increases. Propositions 2 and 4 express that a warlord benefits by being closer to the conflict point both because he invests less in fighting and because he is able to obtain a larger portion of the economy's total amount of goods and services produced.

Propositions 1 through 4 present theoretical evidence in support of some of the previously mentioned empirical studies. Specifically, the model implies a theoretical rationale for Kilcullen's "age of the urban guerilla": Civil, nonstate, and insurrectionist conflicts within the developing world are moving out of jungles and mountains and into cities. Since high-density or harsh terrain causes distant and more rural warlords to increase spending on conflict relative to production, this suggests that policies that seek to increase infrastructure and development-decreasing the value of $\phi$-may lead to an increase in the value of production in the economy as a whole.

\section{Asymmetric exogenous resources}

While exogenous, the effects that asymmetric (unequal) population sizes and preexisting budgets have on each warlord's decisionmaking are important to notice.

Proposition 5: If Assumptions 1 to 3 hold, then both models agree that the number of warriors hired by each warlord - and, hence, the total number of warriors hired within the economy - under equilibrium increases when the population size and/or the preexisting budget of either warlord increases. The models also agree that each warlord will increase his production of goods and services when either his own population size and/or preexisting budget increases and/or when the opposing warlord's population size and/or preexisting budget decreases. In regard to the total production of goods and services within the economy, the subtractive model shows that the total production of goods and services within the economy is unaffected by changes in either warlord's population size and/or preexisting budget while the Gates-logit model finds that an increase in either warlord's population size and/or preexisting budget will increase the total amount of production within the economy.

Proposition 5 is in the same vein as what is known in the literature as the paradox of power: Against the conventional wisdom of divergence, the contestant with fewer resources will fight harder by allocating a larger number of resources toward the conflict than will the better endowed contestant and, given certain conditions, will grow stronger and be left in a relatively better-off position. ${ }^{14}$

Likewise, both models show that as the size of either warlord's population grows and/or the preconflict budget 
increases, the wealthier warlord will invest more in the production of goods and services while the poorer warlord decreases his production. At the same time, the wealthier warlord and the poorer warlord both increase the number of warriors hired. Unlike the concept of the paradox of power, however, neither population size nor the preconflict budget of either warlord affects the CSF or either warlord's overall control of the economy's output. That said, Proposition 5 does express the central idea that the poorer warlord has an advantage in conflict over producing goods and services.

From a position of promoting a policy of peace, Proposition 5 can be a troubling conclusion, because increased funding or support for one warlord will not decrease the level of conflict but aggravate it. The subtractive model agrees that the decrease in the poorer warlord's investment in the production of goods and services is identical to the increase in the richer warlord's: changes in population sizes and preconflict budgets have no effect on the total production within the economy. The interpretation of this scenario is that an increase in one warlord's, say warlord $A$ 's, population size will have him invest more in both warfare and the production of goods and services. To keep up with the escalated conflict effort by warlord $A$, warlord $B$ puts more resources into hiring warriors and dedicates less toward the production of goods and services. As a result, the total production of goods and services within the economy is unaffected by either warlord's resources.

The Gates-logit model result disagrees: Here, the increase in production of goods and services by the wealthier warlord exceeds the decrease in production by the poorer warlord and, hence, population sizes and preconflict budgets do have an increasing effect on total production within the economy. Therefore, if one assumes that the Gates-logit model reflects the mode of a specific conflict, then increasing support for one warlord will result in an expansion of the economy's production even as civil conflict continues. Even though increasing one side's resources may not be the most desired method of ending a conflict, it can be implied that a divergence of resource endowments will occur over time: The wealthier warlord will continue to amass more resources-whether through foreign investment, the sale of goods and services, or the sale of extracted natural resources-while his poorer counterpart's resources dwindle as the conflict game repeats.

\section{Conclusion}

In a seminal paper, Jack Hirshleifer states: "As in all attempts to model complex phenomena, the necessity of making a host of special assumptions limits the applicability of the results obtained [and] in particular ... [t] he effect of distance or other geographical factors have not been considered ... and are not really fundamental." Although he eventually acknowledged it, at the time Hirshleifer ignored Kenneth Boulding's geographic model, pioneered decades earlier. Moreover, Hirshleifer's statement that geographic factors may not be "really fundamental" appears rather incorrect. ${ }^{15}$

This article presents two models wherein two nonparasitic warlords, who are geographically connected, must decide on the amount of resources to be dedicated to conflict and the amount to be dedicated to production. In general, both models conclude that the warlord located closer to the conflict point hires fewer warriors yet wins a greater proportion of the total production within the economy. But it is also shown that some effects on a warlord's decisionmaking process depend on the explicit form of the CSF.

The base model can be extended in a number of important directions. Beyond standard extensions of most microeconomic models (imperfect information, more complex production and consumption functions, repeated games, and so on), the primary extension to be pursued is to abandon the assumption that all of a warlord's production of goods and services are available for appropriation. Instead, the model can be adjusted such that only a portion, dependent on the location of the conflict point, of a warlord's production is under threat of appropriation. Along the same lines, a fair criticism of the model lies in the assumption that each warlord's cache of unextracted natural resources is safe from appropriation.

Since the base model shows that there are no clear advantages to being far away from the conflict point, another adjustment would be to allow the location of each warlord's stronghold to be endogenous. Further, one could advance current research on the choice of weaponry and, hence, destruction by applying the added variable of geographical distance. It is imperative, then, that more research be put into understanding both what defines the conflict point and where warlords choose to establish their territorial stronghold. ${ }^{16}$

\section{Notes}

1. Argentina: See Fearon (2005). Distinct conflict types: To date, there is no official and generally accepted criterion for how a conflict is defined. While it is true that any criteria set will consist of certain arbitrary values/levels, the conversation goes beyond mere semantics. In an exhaustive study, Sambanis (2004) presents a recoding of conflict by answering three questions: What are the thresholds of violence to distinguish conflicts? How does one establish the beginning and end of each conflict? Who are the main players and what political power is wielded by each? While I contend that many nonstate conflicts could also fit into the standard of intrastate and civil conflicts (most insurgencies and civil wars involve parties that disagree as to who has political authority to begin with), I follow the code established by Sambanis and the Correlates of 
War (COW) project in referring to specific types of conflict. Nonstate conflicts identified: Sarkees and Wayman (2010). Microeconomic foundations: Fearon and Laitin (2003).

2. Close to 1.5 billion people: Economist (2011).

3. Definition of warlord economy: Skaperdas (2002). Larger geographical areas: Rustad, et al. (2011). Intensity and duration: Buhaug and Gates (2002); Buhaug, et al. (2009). Urban guerrilla warfare: See Kilcullen (2013). Likelihood of conflict: Buhaug and Röd (2006). Insurgency/weaker groups: Buhaug, et al. (2009).

4. Current warlord models: See Buhaug and Gates (2002); Buhaug, et al. (2009); Rustad, et al. (2011). Territorial expansion: See Findlay (1996); Wittman (2000). Location of insurgence: See Brito and Intriligator (1990,1992). Boulding: See Boulding (1962), especially chapters 4, 12 and 13. Gates: See Gates (2002).

5. A rich set of models: See Garfinkel and Skaperdas (2007).

6. Predator-prey system: Some studies have shown that warlord economies can form and function almost identically to the way organized crime syndicates do. For details, see Reno (1998) and Skaperdas (2001).

7. Conflict models: See Skaperdas (2002). Budget constraints: See Skaperdas (2002); Konrad and Skaperdas (2012).

8. Warlords are referred to in the masculine form. While the vast majority of known warlords are male, there have been cases where women have assumed the role. A notable example has been that of Uganda's Alice Auma/Lakwena. For details, see Eichstaedt (2013).

9. Extracted natural resources: Earlier forms of the model allowed for asymmetric warrior and extraction wages between the two warlords. After an insightful comment from a reviewer, this asymmetry was removed due to the fact that population mobility is restricted and would add little to the model's goals. Future research into such an extension is warranted, however.

10. Invest: This model interprets capital as a basic input into the production of goods and services and does not consider intertemporal issues. Total value of the economy: The model does not include local consumption of the goods and services being produced on the part of either of the two warlords and their respective populations. Therefore, all goods and services being produced within the economy are being sold to an external purchaser, regardless of any and all conflict that may occur.

11. Law of diminishing strength: Boulding labels this condition "the further, the weaker." See Boulding (1962) pp. 229-233. Increase in the cost of travel: Specifically, it is assumed that $\left(\delta \mathrm{I}_{\mathrm{A}}\right) /\left(\delta \mathrm{W}_{\mathrm{A}}\right)>0,\left(\delta \mathrm{I}_{\mathrm{B}}\right) /\left(\delta \mathrm{W}_{\mathrm{B}}\right)>0,\left(\delta \mathrm{I}_{\mathrm{A}}\right) /\left(\delta \mathrm{l}_{\mathrm{A}}\right)<0,\left(\delta \mathrm{I}_{\mathrm{B}}\right) /\left(\delta \mathrm{l}_{\mathrm{B}}\right)>0$, $\left(\delta \mathrm{I}_{\mathrm{A}}\right) /(\delta \Phi)<0$ and $\left(\delta \mathrm{I}_{\mathrm{B}}\right) /(\delta \Phi)<0$.

12. Ratio and difference: For a detailed axiomatic treatment of the CSFs foundations, see Skaperdas (1996); Jia and Skaperdas (2012). Lose everything: Tullock (1980). Different portions of the prize: Hirshleifer (1989). Difference form: See Gates (2002); Buhaug, et al. (2009).
13. For the technical reader, the full treatments, descriptions, and proofs of the pure strategy Nash equilibrium found under the Gates-logit and subtractive impact functions are available in Hionis (2015). This section presents a summary of the main results.

14. Paradox of power: Hirshleifer (1991).

15. Quote: Hirshleifer (1991, p. 198). Eventually: Hirshleifer (2000).

16. Advance current research: See Garfinkel and Skaperdas (2000); Chang and Lou (2012).

\section{References}

Blavatskyy, P. 2010. "Contest Success Function with the Possibility of a Draw: Axiomatization." Journal of Mathematical Economics. Vol. 46, No. 2, pp. 267-276. http://dx.doi.org/10.1016/j.jmateco.2009.11.012

Boulding, K. 1962. Conflict and Defense: A General Theory. New York: Harper and Brothers.

Brito, D. and M. Intriligator. 1990. "An Economic Model of Guerrilla Warfare." International Interactions: Empirical and Theoretical Research in International Relations. Vol. 15, Nos. 3-4, pp. 319-329. http://dx.doi.org/10.1080/03050629008434736

Brito, D. and M. Intriligator. 1992. "Narco-Traffic and Guerrilla Warfare: A New Symbiosis." Defense Economics. Vol. 3, No. 4, pp. 263-274.

Buhaug, H. and S. Gates. 2002. "The Geography of Civil War." Journal of Peace Research. Vol. 39, No. 4, pp. 417-433. http://dx.doi.org/10.1177/0022343302039004003

Buhaug, H., S. Gates, and P. Lujala. 2009. "Geography, Rebel Capability and the Duration of Civil Conflict." Journal of Conflict Resolution. Vol. 53, No. 4, pp. 544-569. http://dx.doi.org/10.1177/0022002709336457

Buhaug, H. and J.K. Rød. 2006. "Local Determinants of African Civil Wars, 1971-2001." Political Geography. Vol. 25, No. 3, pp. 316-335. http://dx.doi.org/10.1016/j.polgeo.2006.02.005

Chang, Y. and Z. Luo. 2013. "War or Settlement: An Economic Analysis of Conflict with Endogenous and Increasing Destruction." Defense and Peace Economics. Vol. 24, No. 1, pp. 23-46. http://dx.doi.org/10.1080/10242694.2012.659862

Clark, D. and C. Raiis. 1998. "Contest Success Functions: An Extension.” Economic Theory. Vol. 11, No. 1, pp.201-204. http://dx.doi.org/10.1007/s001990050184

[Economist] 2011. "The Economics of Violence." The Economist. 14 April 2011.

Eichstaedt, P. 2013. First Kill Your Family: Child Soldiers of Uganda and the Lord's Resistance Army. Chicago, IL: Lawrence Hill Books.

Findlay, R. 1996. "Toward a Model of Territorial Expansion and the Limits of Empire," pp. 41-56 in M. Garfinkel andS. Skaperdas, eds., The Political Economy of Conflict and Appropriation. New York: Cambridge University Press. 
Fearon, J. 2005. "Civil War Since 1945: Some Facts and a Theory." http://igovberkeley.com/sites/default/files/ fearon_endo2007.pdf [accessed 2 June 2014].

Fearon, J.D. and D. Laitin. 2003. "Ethnicity, Insurgency and Civil War." American Political Science Review. Vol. 97, No. 1, pp. 75-90. http://dx.doi.org/10.1017/S0003055403000534

Garfinkel, M.R. and S. Skaperdas. 2000. "Conflict without Misperceptions or Incomplete Information." Journal of Conflict Resolution. Vol. 44, No. 6, pp.793-807. http://dx.doi.org/10.1177/0022002700044006005

Garfinkel, M.R. and S. Skaperdas. 2007. "Economics of Conflict: An Overview," pp. 649-710 in T. Sandler and K. Hartley, eds. Handbook of Defense Economics. Amsterdam: Elsevier.

Gates, S. 2002. "Recruitment and Allegiance: The Microfoundations of Rebellion." Journal of Conflict Resolution. Vol. 46, No. 1, pp. 111-130. http://dx.doi.org/10.1177/0022002702046001007

Hionis, J. 2015. “Online supplement: Nonparasitic warlords and geographic distance." The Economics of Peace and Security Journal. Vol. 10, No. 1. http://dx.doi.org/10.15355/epsj.10.1.5s

Hirshleifer, J. 1988. "The Analytics of Continuing Conflict." Synthese. Vol. 76, No. 2, pp. 201-233. http://dx.doi.org/10.1007/BF00869589

Hirshleifer, J. 1989. "Conflict and Rent-Seeking Success Functions: Ratio vs. Difference Models of Relative Success." Public Choice. Vol. 63, No. 2, pp. 101-112. http://dx.doi.org/10.1007/BF00153394

Hirshleifer, J. 1991. "The Paradox of Power." Economics and Politics. Vol. 3, No. 3, pp. 177-200. http://dx.doi.org/10.1111/j.1468-0343.1991.tb00046.x

Hirshleifer, J. 2000. "The Macrotechnology of Conflict." Journal of Conflict Resolution. Vol. 44, No. 6, pp. 773-792. http://dx.doi.org/10.1177/0022002700044006004

Jia, H. and S. Skaperdas. 2012. "Technologies of Conflict," 449-472 in M. Garfinkel and S. Skaperdas, eds. The Oxford Handbook of The Economics of Peace and Conflict. New York: Oxford University Press.

Kilcullen, D. 2013. Out of the Mountains: The Coming Age of the Urban Guerrilla. New York: Oxford University Press.

Konrad, K. 2007. "Strategy in Contests: An Introduction." wZB-Markets and Politics Working Paper No. SP II 2007-01. http://www.econstor.eu/bitstream/10419/ 51106/1/565198513.pdf [accessed 1 September 2014].

Konrad, K. and S. Skaperdas. 2012. "The Market for Protection and the Origination of the State." Economic Theory. Vol. 50, No. 2, pp. 417-443. http://dx.doi.org/10.1007/s00199-010-0570-x

Moldovanu, B. and A. Sela. 2001. "The Optimal Allocation of Prizes in Contests." American Economic Review. Vol. 91, No. 3, pp. 542-558. http://dx.doi.org/10.1257/aer.91.3.542

Münster, J. 2009. "Group Contest Success Functions." Economic Theory. Vol. 41, No. 1, pp. 345-357. http://dx.doi.org/10.1007/s00199-009-0479-4

Rai, B. and R. Sarin. 2009. "Generalized Contest Success Functions.” Economic Theory. Vol. 40, No. 1, pp. 139-149. http://dx.doi.org/10.1007/s00199-007-0328-2

Reno, W. 1998. Warlord Politics and African States. Boulder, CO: Rienner.

Rustad, S.A., H. Buhaug, A. Falch, and S. Gates. 2011. "All Conflict is Local: Modeling Sub-National Variation in Civil Conflict Risk." Conflict Management and Peace Science. Vol. 28, No. 1, pp. 15-40. http://dx.doi.org/10.1177/0738894210388122

Sarkees, M. and F. Wayman. 2010. Resort to War: A Data Guide to Inter-State, Extra-State, Intra-State and Non-State Wars, 1816-2007. Washington, D.C.: CQ Press.

Skaperdas, S. 1996. "Contest Success Functions." Economic Theory. Vol. 7, No. 2, pp. 283-290.

http://dx.doi.org/10.1007/s001990050053

http://dx.doi.org/10.1007/BF01213906

Skaperdas, S. 2001. "The Political Economy of Organized Crime: Providing Protection When the State Does Not." Economics of Governance. Vol. 2, No. 3, pp. 173-202. http://dx.doi.org/10.1007/PL00011026

Skaperdas, S. 2002. "Warlord Competition." Journal of Peace Research. Vol. 39, No. 4, pp. 435-446. http://dx.doi.org/10.1177/0022343302039004004

Tullock, G. 1980. “Efficient Rent Seeking," pp. 97-112 in J. Buchanan, R. Tollison, and G. Tullock, eds. Toward a Theory of the Rent-Seeking Society. College Station, TX: Texas A \& M University Press.

Wittman, D. 2000. "The Wealth and Size of Nations." Journal of Conflict Resolution. Vol. 44, No. 6, pp. 868-884. http://dx.doi.org/10.1177/0022002700044006010 